in the range of $2,550-2,850 \mathrm{k} . c a l . / \mathrm{lb}$. for Indian coal. The average may be taken to be about $2,700 \mathrm{k}$.cal./lb. Hence for complete combustion $1 \mathrm{lb}$. of coal gives as much heat as $1.8 \mathrm{lb}$. of dried cow-dung. Thus the contribution of cow-dung fuel to the fuel economy of India is equivalent to 40 million tons of coal.

Fuel wood. The position with respect to fuel wood is not very clear. Recorded figures of fuel wood consumption from lands classified as forests indicate an extremely low value, being only about $53 \mathrm{lb}$. per head per year. According to the President of the Forest Research Institute and Colleges, India, this is a ridiculously low figure (private communication). However, there are reasons for believing that unauthorized wood-cutting amounts to many times the recorded figures, and that leaves and twigs are also utilized as fuel ${ }^{3}$. Actually, some idea regarding the amount of domestic fuel wood burnt annually in India may be obtained in the following manner.

According to Lahiri and Das Gupta ${ }^{3}$, the average per capita energy consumption in India amounts to about $80-100$ therms per year, which is equivalent to about $2,800 \times 10^{12}$ to $3,500 \times 10^{12}$ B.T.U. a year for the entire population. Of this, about $1,100 \times 10^{12}$ B.T.U. a year is met from coal, oil and hydroelectricity. The remainder must therefore come from wood fuel and farm waste. The energy obtained from these sources must therefore be in the range of $1,700 \times 10^{12}$ to $2,400 \times 10^{12}$ B.T.U. We may therefore assume that about $2,000 \times 10^{12}$ B.T.U. or $500 \times$ $10^{12} \mathrm{k} . c a l$. of energy are obtained in India per annum by burning wood fuel and farm waste ${ }^{2,3}$. Taking the heating value of 40 million tons coal-equivalent of cattle dung to be about $242 \times 10^{12} \mathrm{k}$.cal., the heating value of fuel wood should be about $258 \times 10^{12}$ k.cal., that is, equivalent to 43 million tons of coal approximately. This would bring the per capita consumption of fuel wood in India to about $370 \mathrm{lb}$. per head per year, which is about seven times the figure quoted above.

\begin{tabular}{|c|c|c|}
\hline Fuel & $\begin{array}{c}\text { Coal } \\
\text { equivalent } \\
\text { in million } \\
\text { tons consumed } \\
\text { annually }\end{array}$ & $\begin{array}{l}\text { Percentage } \\
\text { contribution } \\
\text { to the fuel } \\
\text { economy of } \\
\text { India }\end{array}$ \\
\hline $\begin{array}{l}\text { Coal } \\
\text { Oil and hydroelectricity } \\
\text { Cattle dung } \\
\text { Wood, dried leaves and twigs }\end{array}$ & $\begin{array}{r}35 \\
7 \\
40 \\
43\end{array}$ & $\begin{array}{r}28 \cdot 0 \\
5 \cdot 6 \\
32 \cdot 0 \\
34 \cdot 4\end{array}$ \\
\hline
\end{tabular}

We are now in a position to estimate the percentage contribution of different types of fuels to the fuel economy of India. This is shown in Table 3.

1 Putnam, P. C., "Energy in the Future" (London : Macmillan, 1954). ${ }^{2}$ Lahiri, A., and Das Gupta, A. K., "Problems of Energy Development in India"-I, Fuel Res. Inst. News, 4, No. 3 (1954).

${ }^{3}$ Lahiri, A., and Das Gupta, A. K., "Problems of Energy Development in India"-II, Fuel Res. Inst. News, 4, No. 4 (1954).

4 Bhabha, II. J., "The Role of Atomic Power in India and Its Immediate Possibilities", International Conference on the Peaceful mediate Possibilities", Internation
Uses of Atomic Energy (1955)

'Lahiri, A., "Domestic Fuel", Fuel Res. Inst. News, 3, No. 3 (1953).

- Agricultural Marketing Advisor to the Government of India. Report on the Marketing of Cattle in India, 66 (1946).

"Planning Commission, "The First Five Year Plan-A Draft Outline", 109 (1951).

${ }^{8}$ Advisory Board of the Imperial Council of Agricultural Research. Memorandum on the Development of Agriculture and Animal IIusbandry in India, 27 (1944).

${ }^{8}$ Ministry of Food and Agriculture. Report of the Expert Committee on Manures and Fertilizers, 34 (1953).

${ }^{10}$ Burns, W., "Technological Possibilities of Agricultural Development in 'Indja", 116 (1944).

\section{THE U.S. NATIONAL ACADEMY OF SCIENCES}

\section{ANNUAL MEETING}

THE ninety-third annual meeting of the National Academy of Sciences was held in Washington, D.C., during April 23-25. At the annual dinner on April 24, there were two guests of honour: Dr. Alexander von Muralt, past president of the International Council of Scientific Unions, and now president of the National Research Council of Switzerland and rector of the University of Berne ; and Dr. John E. Burchard, dean of the School of Humanities and Social Studies at the Massachusetts Institute of Technology, and president of the American Academy of Arts and Sciences. Thirtyfour papers were read at five sessions, and, in addition, three other sessions were devoted to symposia on the following subjects: solar and terrestrial relationships ; biomolecular organization and life processes; and science in education.

At the meeting the following awards of the Academy were presented: Agassiz Medal, to Prof. Alfred C. Redfield, associate director of the Woods Hole Oceanographic Institution; Henry Draper Medal, to Prof. Hendrik C. van de Hulst, professor of theoretical astronomy in the University of Leyden ; Elliot Medal, to Prof. Archie Carr, professor of biological sciences in the University of Florida; Kimber Genetics Award, to Prof. Sewall Wright, professor of genetics in the University of Wisconsin; Kovalenko Medal, to Dr. Peyton Rous, member of the Rockefeller Institute for Medical Research; Thompson Medal, to Prof. Alfred S. Romer, Alexander Agassiz professor of zoology and director of the Museum of Comparative Zoology, Harvard University; Watson Medal, to Dr. Chester B. Watts, director of the Six-Inch Transit Circle Division, United States Naval Observatory.

The Agassiz Medal of the Academy, which is awarded for distinguished work in oceanography, goes to Dr. Redfield in recognition of his many and diverse contributions in this field. $\mathrm{He}$ has been associated with the Woods Hole Oceanographic Institution since 1931 and has been professor of physiology in Harvard University since the same date. His knowledge of physiology, a field in which he made important contributions before turning to the study of the sea, coupled with his interest in sailing and the seashore, has been an important part of his work in oceanography. For example, he translated the physiological functions of blood into the metabolism of the marine environment in which water and organisms interact as an entity with a physiology of its own. His analyses of biochemical cycles in the sea, of the origin and distribution of organisms, and of the products of biological activity have led to interpretations of the oceanic circulation which incorporate the physical, chemical and biological cycles. Lately he has been studying the development and growth of salt marshes and the genesis and propagation of waves associated with hurricanes.

The Draper Medal, which was established to recognize significant contributions to astronomical physics, has been awarded to Prof, van de Hulst for his noteworthy contributions to the field of radio astronomy and in particular for his prediction, made in 1944 , that radiation of $21 \mathrm{~cm}$. wave-length should be emitted by neutral hydrogen in interstellar space. 
The probability of the transition in a given atom is extremely low; but because the total quantity of hydrogen in the vast reaches of interstellar space is enormous, detectable amounts of the radiation are emitted. In 1951 observers in the United States, Australia and the Netherlands detected the radiation independently as a sharp line in the radio-frequency spectrum. Because of its sharpness, the line is useful for the determination of the velocities at which the clouds of hydrogen are moving towards us or away from us, and because radiation at this frequency penetrates regions relatively opaque to visible light, the observations have contributed much to the great new fund of knowledge that comes from the rapidly growing field of radio astronomy. Soon after his prediction was confirmed by observation, Prof. van de Hulst, in collaboration with Jan Oort and C. A. Muller, began to study the hydrogen radiation around the equator of our galaxy, and by 1953 they had produced evidence of the spiral structure of the galaxy in striking agreement with observations by other means.

The award of the Daniel Giraud Elliot Medal has been made to Dr. Carr in recognition of his book, "Handbook of Turtles: the Turtles of the United States, Canada, and Baja California" (Comstock Publishing Associates, Cornell University Press, 1952). Dr. Carr has devoted a number of years in the field and the laboratory to the study of the anatomy and zoology of the turtle, and his "Handbook" is an account of all kinds of turtles found in the area north of Mexico, but including Lower California. After discussing the probable evolution of the turtle group with a summary of physiology, adaptation, anatomy and economic value, he describes the various kinds of turtles and their distribution, their appearance being illustrated by many excellent photographs and drawings. The Elliot Medal has been awarded by the Academy annually since 1917, under a provision of the will of Daniel Giraud Elliot expressing his wish to provide a medal and honorarium to the author of any paper, essay or other published work of outstanding merit in zoology or palæontology.

Prof. Wright, the recipient of the Kimber Genetics Award, has made important contributions to both theoretical and experimental genetics. His early experimental work was concerned with the effects of inbreeding in animals, and this led to studies on the relative importance of heredity and environment as causes of variation. His later work has dealt with the problems of physiological and developmental genetics, and, using guinea pigs, he has analysed the complex and remarkable interaction effects of genes. In theoretical genetics, Prof. Wright is perhaps best known for his series of mathematical papers on various aspects of evolution. His theoretical work on the statistical consequences of Mendelian heredity, although directed primarily to the problem of evolution, has had profound effects on the methods by which domestic plants and animals are genetically improved.

The award of the Kovalenko Medal to Dr. Rous is in recognition of his distinguished contributions in the field of experimental medicine. Very early in his career he observed an association between viruses and tumour growth. Because he was so far in advance of his field, working at a time when knowledge of viruses was meagre and cancer research was in its infancy, the significance of this relationship was not at first recognized. For the past two decades he has been actively concerned with the viral etiology of tumours. He has also worked on the physiology and pathology of the liver and the physiology of the blood vessels. In addition, he has been editor of the Journal of Experimental Medicine for many years. The Kovalenko Medal was established in 1949 by Dr. M. S. Kovalenko in memory of his wife, Jessie Stevenson Kovalenko, for outstanding contributions to medical science, and Dr. Rous is the second recipient.

Prof. Romer, the recipient of the Thompson Medal, has spent most of his research career studying the comparative anatomy and evolution of vertebrate animals. His speciality has been the reptilian and amphibian life of the Permian period, some 200-225 million years ago, soon after the vertebrates in the course of their evolution had emerged from the water and as their conquest of the land was getting well under way. In this connexion he has shown that the ancestral freshwater fishes already had lungs and other pre-adaptations for land life, and has developed the theory that legs, capable of walking on land, were originally an adaptation for staying in the water. They permitted the ancestral fishes to wriggle from a drying pool across land to other pools still holding water in seasons of drought. Especially noteworthy are his intricate studies of details of the brain-case and reconstruction of vanished nerves in fishes, amphibians and reptiles long extinct. Prof. Romer has himself discovered and collected many of the rare fossil animals that he has studied; he has led many fossil-hunting expeditions, especially in Texas.

Dr. Watts, who receives the James Craig Watson Medal in recognition of his outstanding contributions to astronomical research, has spent the greater part of his forty-five years at the United States Naval Observatory, determining positions of the Sun, Moon, planets and stars; and since 1934 he has been chiefly responsible for the six-inch transit circle, and with a judicious combination of mechanical, optical, photographic and electronic techniques, he has brought the instrument to an extremely high state of perfection. He has recently designed and supervised the construction of a now nine-inch transit circle at the Observatory. The precision of all these measurements is based on observations of the edge of the Moon's disk, and the edge is always irregular because of the high mountains and low valleys on the Moon's surface and also because a slightly different aspect of the edge is seen from time to time. About eleven years ago, Dr. Watts undertook to survey that part of the Moon's surface (comprising some 18 per cent) which is seen as an edge. To survey a surface a quarter of a million miles away to an accuracy of fifty feet required some thousand photographs, the invention and construction of an automatic photoelectric machine for tracing the profile of each photograph and drawing it on a strip of paper $30 \mathrm{ft}$. long, the design and construction of analogue computers for analysing the profiles and translating them into numerical form, the devising of means for integrating the profiles into a representation of the surface of the Moon in the vicinity of the edge, and finally the development of the most readily usable form for publication of the results. The survey is now complete and will be published shortly.

The following new elections were made to the Council of the Academy : Treasurer, Dr. William J. Robbins, director of the New York Botanical Garden, New York (this being the second such term of office 
for which he has been elected treasurer); Members of Council, Prof. I. I. Rabi, professor of physics, Columbia University, New York, and Dr. F. E. Terman, dean of the School of Engineering, Stanford University, Stanford, Calif. The other officers of the Academy, who were elected in previous years and will continue until expiry of their terms of office, are as follows: President, Dr. Detlev W. Bronk; VicePresident, Dr. George W. Corner ; Home Secretary, Dr. Hugh L. Dryden; Foreign Secretary, Prof. John Gamble Kirkwood; Members of Council, Prof. Farrington Daniels, Dr. E. A. Doisy, Dr. James Gilluly, Dr. Theophilus S. Painter, Dr. Merle A. Tuve and Prof. Edwin B. Wilson.

The following have been elected members of the Academy : G. von Békésy, senior research Fellow in psychophysics, Harvard University; M. Benedict, professor of nuclear engineering, Massachusetts Institute of Technology ; K. E. Bloch, professor of chemistry, Harvard University ; K. S. Cole, director of the Laboratory of Biophysics, National Institute of Neurology, Diseases, and Blindness, National Institutes of Health, Bethesda; B. L. Crawford, jun., professor of physical chemistry, University of Minnesota; W. A. Fowler, professor of physics, California Institute of Technology; C. P. Haskins, president of the Carnegie Institution of Washington; E. W. Haury, professor of anthropology, University of Arizona ; P. Kusch, professor of physics, Columbia University; A. L. Lehninger, professor of physiological chemistry, School of Medicine, Johns Hopkins University; M. G. Mayer, senior physicist, Argonne National Laboratory, Lemont; C. P. Miller, professor of medicine, University of Chicago; W. W. Morgan, professor of astronomy, Yerkes Observatory, University of Chicago; W. H. Munk, professor of geophysics, Scripps Institution of Oceanography, La Jolla ; M. S. Newman, professor of chemistry, Ohio State University ; R. F. Pitts, professor of physiology, Cornell University College of Medicine; J. D. Roberts, professor of organic chemistry, California Institute of Technology ; K. P. Schmidt, emeritus curator, Department of Zoology, Chicago Natural History Museum ; M. Schwarzschild, professor of astronomy, Princeton University; C. E. Shannon, research mathematician, Bell Telephone Laboratories, Inc.; F. K. Skoog, professor of botany, University of Wisconsin; N. E. Steenrod, professor of mathematics, Princeton University; W. H. Stockmayer, professor of physical chemistry, Massachusetts Institute of Technology ; A. Szent-Györgyi, director of rosearch, Institute for Muscle Research, Inc., Marine Biological Laboratory, Woods Hole, Mass.; C. H. Townes, professor of physics, Columbia University ; F. J. Turner, professor of geology, University of California, Berkeley; J. Verhoogen, professor of geology, University of California, Berkeley; M. B. Visscher, professor of physiology, University of Minnesota; J. C. Warner, president of the Carnegie Institute of Technology, Pittsburgh; W. H. Zinn, director of the Argonne National Laboratory, Lemont.

'The following have been elected foreign associates of the Academy : Prof. F. G. Gregory, director of the Research Institute of Plant Physiology and professor of plant physiology, Imperial College of Science and Technology, London; Sir K. S. Krishnan, director of the National Physical Laboratory, New Delhi ; Prof. A. E. Michotte, professor of psychology, University of Louvain; and Prof. J. J. C. Pérès, dean of the Faculty of Sciences and professor of rational mechanics, University of Paris.

\section{FORESTRY COMMISSION}

\section{REPORT FOR 1954}

$T$ HE annual report of the Forestry Commission for $1954^{*}$ opens with a statement on the un. veiling of a memorial on the site in Keilder Forest where the ashes were scattered of the late Lord Robinson, chairman of the Forestry Commission during 1932-52 and a member of the Commission from its inception.

The year 1954 marks the peak of the Commission's planting so far, a total of 70,400 acres having been achieved, or 2,800 acres more than the previous year. Since the end of the Second World War the rate of annual planting has been increased each year up to this major total. The regular increase, it is noted, has only been maintained by materially reducing the reserves of land awaiting planting. So the point has been reached when the annual planting programme will not only not increase but will in fact fall. The report states that the planting to be carried out in 1955 will bring the planted forest area under the Commission up to and beyond the million acres mark: a truly remarkable and meritorious performance, with all the difficulties and setbacks the Commission has had to face since its inception in 1920, when five million acres of forests were aimed at. More land is required; but the problem is not, merely one of acquiring land, for it must be suitably distributed plantable land. There are still large tracts of country running into many hundreds of thousands of acres the best use of which is undoubtedly forestry. It is this type of land which the Commission wishes to acquire if the owners are unable to plant it themselves. Private planting continues to rise steadily though surely : including areas planted without grants, a total of 19,100 acres were planted-nearly a thousand acres more than the previous year.

The production and consumption of home timber were the same as during 1953. The cut in hardwood species was probably less, due to the poorer quality of the timber now being felled and to the abolition of softwood consumer licences in November 1953. It is interesting to note that the expensive home-grown programme inaugurated in 1919 is now beginning to show a financial return, in the pulp and pitwood markets, though difficulties with reference to mining timber and its testing for quality are still under debate. The big Scottish windblow of January 1953 has continued to provide large amounts of timber, of which the National Coal Board has taken advantage. The large intake of home pit-props by the English collieries has been due to an increase in normal production - a most satisfactory position in view of the fact that at the beginning of the century, and before and after, the mines were dependent on Scandinavian and other imports at great cost. Nevertheless, only about one-quarter of the estimated consumption of Britain as a whole is being supplied from home sources.

An interesting investigation is in the possible utilization of inferior and poorly grown hardwoods for wood pulp. The main bulk of these hardwoods are to be found in the south of England, and two British paper-making groups are considering the question of ground wood-pulp for newsprint and

- Forestry Commission. Thirty-ffth Annual Report of the Forestry Commission for the Year ended September 30th, 1954. Pp. 88 . (London: H.M.S.O., 1955.) 3s. 6d. net. 